\title{
A web of orixás: Technology and the transmission of Candomblé songs in Bahia and Berlin
}

\author{
Nina Graeff \\ PhD in Anthropology of Education \\ Visiting professor at the Department of Music Education of \\ Universidade Federal da Paraíba (UFPB) \\ ninagraeff@hotmail.com
}

\begin{abstract}
This paper draws upon ethnographic field research on the transmission of the Afro-Brazilian religion of Candomble in two contrastive contexts: Reconcavo da Bahia and Berlin. Whereas in the religion's original region, Bahia, people are immersed in a universe of orixás, Candomblé's deities, in Germany a context must be created for its practice. In this context, the difficulties of learning songs in foreign languages - Yoruba and Portuguese - become. Technology facilitates the transmission of Candomble by enabling the worldwide circulation of cultural references, such as lyrics of orixás songs and videos of rituals, and by connecting practitioners to its symbology, songs and dances despite the distance from Brazil. Paradoxically, although in Bahia technology is considered an additional tool for learning, in Berlin, where references lack, it brings about controversies. This paper seeks to demonstrate through this paradox the intricacies of practical learning as well as of the interrelation between practice and discourse.
\end{abstract} Keywords: Candomblé; Bodily Knowledge; Practical Learning; Transculturality; Internet.

\section{Na rede com os orixás: Tecnologia e transmissão de cantigas de Candomblé na Bahia e em Berlim}

Resumo: Este artigo parte de pesquisa etnográfica sobre a transmissão da religião afro-brasileira do Candomblé em dois contextos contrastantes: o Recôncavo da Bahia e Berlim. Enquanto na região de origem da religião, Bahia, as pessoas se encontram imersas em um universo de orixás, deuses africanos, na Alemanha é necessário criar um contexto para a sua prática. Neste contexto, as dificuldades de memorizar cantigas em línguas estrangeiras - iorubá e português - se evidenciam. Tecnologias facilitam a transmissão do Candomblé ao permitirem circular diversas referências culturais, de vídeos dos rituais a cantigas de orixás, e por conectarem imigrantes e estrangeiros à sua simbologia, cantigas e danças, apesar da distância do Brasil. Paradoxalmente, embora na Bahia tecnologias sejam consideradas uma ferramenta adicional de aprendizagem, em Berlim, na ausência de referências, tecnologias trazem à tona controvérsias. Este artigo busca demonstrar através desse paradoxo a complexidade da aprendizagem prática, assim como da correlação entre discurso e prática.

Palavras-chave: Candomblé; Conhecimento Corporal; Aprendizagem Prática; Transculturalidade; Internet. 


\title{
Introduction
}

In the Afro-Brazilian religion of Candomble ${ }^{1}$, learning is not only experiential, arising from collectively shared bodily practices (GRAEFF, 2014a, 2014b, 2016, 2018), but has experience itself as a main purpose ${ }^{2}$. It is not about the memorization and accumulation of knowledge, but rather an experiential path towards wisdom; towards sensing and cultivating axé, the force of life:

\begin{abstract}
The essence of our religion is axé (the magic that takes place), which is transmitted in secret practices by those who have received it. Practice and theory complement each other, but what happens with the force that was passed down? Who did not receive axé cannot pass it on [...], no matter how much practical and theoretical knowledge one has. It is as if someone would read a recipe book, cook a beautiful cake, but with poison inside. In Candomblé one doesn't skip [learning] steps. Everything must take place at the right time (SANTOS, 2010:141. trans. by author).
\end{abstract}

Nevertheless, technology - writing, audio recordings, videos, among others, and especially the internet - is increasingly used in the transmission of the religion. For understanding the dynamics of transmission of bodily knowledge transculturally, I undertook a Ph.D. research on Candomblé in Berlin and Bahia ${ }^{3}$.

In the cosmopolitan city of Berlin, Brazilians from diverse regions as well as Europeans, North and South-Americans, Israelis and Africans from different social fields meet weekly at Ilê Obá Sileké, the sole Candomblé temple in Germany ${ }^{4}$. In Santo Amaro da Purificação ${ }^{5}$, Bahia, a town that was one of Brazil's first Portuguese settlements, believers and houses praising the orixás $^{6}$ are not only numerous but all-pervading. What all these individuals have in common is the wish to share and spread axé, even if the literal meanings of its liturgical language, Yoruba, and of the ritual structure might be ignored (GRAEFF, 2018). Instead of drawing a comparison between both cultural contexts, my research seeks to stress their "entanglements, intersections and transitions" (WELSH, 1999: 205), that is, the transculturality of Candomble experience.

1 The bibliography about Candomble is vast, the reader may find a comprehensive and critical literature review of the religion by Goldman (2005). More recently, transnational studies on orixás religions (OLUPUONA \& REY, 2008) as well as on Candomble have been made, such as those by Capone (2001) and Matory (1999, 2005), who investigated Candomblé in Bahia and in the United States. Matory mentions his experience at the Berliner Candomble community in a recent book (MATORY, 2018). Other researchers have conducted fieldwork on the community, whose work, however, was not well received by its members. The role of writing in Candomblé was explored by Castillo (2008) and that of the internet has attracted more and more attention in academic publications (e.g. FREITAS, 2014, 2019; PEREIRA \& CAPUTO, 2014; PREVITALLI, 2014; MESSIAS \& DANON, 2017), none of which follows a phenomenological approach to the learning of songs nor compares different contexts of transmission.

2 My research gives primacy to Candomblé's own contexts, agents and processes of knowledge production, which rely mostly on practice and not on theories, pursuing thereby an "ecology of knowledges" (SANTOS, 2007). Its main sources are the experiences collectively shared in rituals and in everyday life. Similar to newcomers in Candomblé, who don't receive any theoretical introduction to the religion nor to other practitioners, I only contextualize Candomblé, the researched contexts and practitioners when necessary for the discussion.

3 The fieldwork in Berlin began in April 2013 and did not end, for I became a member of the community. The official period of ethnographic data collection extended from July 2013 till March 2014. Fieldwork in Bahia lasted from October 2014 until beginning of February 2015.

4 The house was officially founded in 2008 by Babalorixá Muralesimbé, also known as Murah Soares. It is located in the famous neighborhood of Kreuzberg, sharing space with the intercultural center "Forum Brasil", managed by Murah and by the German psychotherapist Martin Titzck.

5 Santo Amaro da Purificação is located $73 \mathrm{~km}$ away from Bahia's capital, Salvador. 
Orixás are forces of nature. As such, in Bahia orixás are, as many Bahians say, "the air one breathes": not only are the forces of nature everywhere in the tropical region surrounding Salvador, but an abundance of orixás references pervades one's life since birth. Even uninterested people cannot ignore their presence, absorbing them through a lifelong immersion in what can be called a universe of orixás. In Berlin, especially in winter, orixás seem rather to hibernate: most sacred herbs and food ingredients used in ritual offerings are difficult to find and cultivate. For most practitioners, Candomblé only exists during rituals inside the temple on Wednesdays, as well as during five public festivities per year. These are the sole opportunities, and were the first opportunities for most members including Brazilians, of experiencing and getting familiar with the religion in Germany.

Among others, the difficulties of memorizing lyrics in foreign languages - Yoruba and Portuguese - become evident in a cosmopolitan, international context. In this, technology should facilitate cultural transmission by providing references, from lyrics of orixás songs to videos of rituals, and connecting migrants and foreigners to its symbology, myths, songs and dances despite their physical distance from Brazil. Paradoxically, in Berlin, where references lack, the use of technology brings about controversies in the transmission of knowledge, becoming a taboo. Within a universe of orixás, where their references are abundant, technology works as only one among several transmission tools.

While unveiling different modes of learning Candomblés bodily knowledge from a phenomenological approach, this paper seeks to demonstrate the intricacies of practical learning as well as of the interrelation between practice and discourse regarding the use of technology in Candomblé. Therefore, the first section contextualizes the learning of lyrics in foreign languages in the first field context researched, Berlin, while the second draws parallels between this and the second one, Bahia, confronted after one and a half year frequenting Candomblé in Germany. The last section reflects upon the different uses of internet and the interrelations between practice and discourse in both investigated contexts.

\section{Learning lyrics in foreign languages in Berlin}

For most practitioners both in Berlin and Bahia, the greatest challenge in learning cantigas de Candomblé ("Candomble chants") is to memorize their Yoruba lyrics due to the lack of references of Yoruba sounds, phonemes and meanings. In Candomblé kétu ${ }^{7}$, Yoruba functions as a ritual language, used only in liturgical functions and not as an interpersonal everyday language.

Certainly, there are elders who still speak the language, but during my fieldwork in Berlin Ogã Paraná ${ }^{8}$ was the only elder I experienced building sentences instead of merely using words or expressions in Yoruba. As a consequence, much of the words' literal content gets lost, the masters are not very sure about the words' meanings and the importance of knowing them is relativized (GRAEFF, 2018). Besides, Yoruba is an oral and tonal language' ${ }^{9}$ transliterated into the Latin alphabet only mid of the $19^{\text {th }}$ by a missionary and former slave $e^{10}$. The transliteration uses diacritic signs for tones and other specific sounds, so that only a few elders know how to speak it and even less Candomblé practitioners know how to write and read it.

\footnotetext{
6 For writing Candomblé words of Yoruba or other African origins I choose the Portuguese spelling, as mostly used by Brazilians.

7 There are different Candomblé traditions, called nações. At the time of my fieldwork, both Candomblé houses investigated were aligned with the West-African kétu tradition.

8 Male ogã (the ritual function of male drummers, among others) originally from São Paulo (60+).

9 In tonal languages, one same phoneme may have different meanings depending on their tone, that is, their melodic direction.
}

10 Bishop Samuel Ajahyi Crowther. See Ayoh'Omidire (2005:107). 
Ilê Obá Sileké is a highly transcultural Candomblé community located in the famous neighbourhood of Kreuzberg in Berlin since 2008 and led by the pai de santo ${ }^{11}$ Babalorixá Muralesimbé, also known as Murah". Every Wednesday at 9 a.m. the egbé ("community" in Yoruba) of Ilê Obá Sileké meets to praise the orixás throughout the day. In June 2016, the egbé officially consisted of over twenty members, of which four Germans, one North-American and the others from different parts of Brazil; from its very South, like me, to the North, like Forró Alabê from Pará. Further people contribute more or less directly to the house, though not officially. Especially at public rituals, practitioners initiated in other houses from Brazil and even in other traditions and countries such as Santería from Cuba come to support and participate. Candomble in Berlin is open to everyone; experienced guests are welcome to dance in the circle and receive their orixás.

At the very beginning of my fieldwork in 2013, the newcomer Ogã Paulo ${ }^{13}$ became responsible for teaching cantigas de Candomblé to members of Ilê Obá Sileké (GRAEFF, 2014a). He started learning Yoruba in Berlin by means of autodidactic material from the internet the same year and to take classes with a Nigerian teacher one year later. Since the first "cantiga classes"14 he gave us, he was aware of the problem imposed by the transliteration of the lyrics:

Today we would begin learning to sing $x i r \hat{e}^{15}$. [I asked Ogã Paulo:] 'is it on paper?' [Paulo:] 'no, this is not even the plan... For Caboclo songs (chants for indigenous spirits) it would be ok, but not for xirê. Even because one cannot write in Yoruba: should one write it wrong? Thus, it's better not to write... No one here knows Yoruba [...], not even Murah, no one knows how to write it correctly, with the proper separations and terminations...' (Field note from 14.10.2013, Santo Amaro).

That was minutes before our second cantiga class, the first on xirê, that is, on songs specifically for the orixás. Ogã Paulo explained very confidently that we were not supposed to use pre-written lyrics. What we did was to listen to his singing and write it down the way we heard it, which should facilitate the memorization.

Nevertheless, he soon noticed it would be more effective to bring us some copies of lyrics, which we could immediately associate with what we were singing. As he said, it was not the "plan" to use "paper", but plans change situatively, according to the context's needs, as further explored in the next sections.

In ilê the overall tendency to perceive, interpret and reproduce something within one's system of references is noticeable and seems to take place both conscious and unconsciously. One can draw associations of Yoruba phonemes with Portuguese, as the phonemes "maman", which Brazilians can easily associate with mamãe (mommy) and immediately memorize it. The interpretation of Xangô's greeting "kawo kabiesile" was also once interpreted as "olha a cabeça dele" ("look at his head") by a member. Even Babalorixá Muralesimbé brought up his first associations of Yoruba lyrics with Portuguese as a child in Brazil, in order to remind us of the low and long process of learning cantigas, which is often accompanied by several mistakes:

11Pai de santo in Portuguese and babalorixá in Yoruba refer to Candomblé's male priest. The female priest is called mãe de santo and ialorixá, respectively.

12 Babalorixá Muralesimbé (50+) grew up in Salvador in the house of his grandmother, who was a mãe de santo. In 1989, Murah was invited by Tanzfabrik to give a two-week workshop on Afro-Brazilian dance, which, due to its great success, was extended to weeks, then months, until Murah got hired for several years.

13 Candomblé member from Bahia (30+), who became "ogã suspenso" of Ilê Obá Sileké in 2013.

14 In the beginning of my fieldwork, Ogã Paulo would teach cantigas to ilê members on Mondays, in what we used to call ", aulas de cantiga“" (cantiga classes). For more details see Graeff, 2014b

15 Xirê is a ritual sequence of the orixás, referring to the order they are called in a ritual as well as to the repertoire of songs following this order. 
When I was a child, I also learned. Children learn whatsoever and everything is Portuguese for them, you know? When I was a child, for instance... "Alakoro eleun o" - for me, being a kid, I thought "[Alakoro] ele é um" ("he is one"), in my head it was like this. It has nothing to do do [with the Yoruba meaning], it's not about "he is one". It has nothing to do with Portuguese but for me it was Portuguese [sings]. Until my father came and explained it to me. But I could already sing the melody, the song, so I could immediately switch it [the phonemes]. That's how it is... (Babalorixá Muralesimbé during recorded cantigas class on 03.03.2014, Berlin, trans. by author).

If human perception is based on past experiences (MERLEAU-PONTY, 1962), these build the system of references humans employ while perceiving, analysing and learning, that is, embodying new contents such as Yoruba lyrics. Without references of it, one automatically draws upon linguistic systems already internalized, especially one's mother tongue. In the case of meaningless signs such as "ja ba lo ê", from which I cannot recognize more than unrelated syllables, memorization is far from being as effective as phonemes that remind me of "mommy". Merleau-Ponty enlightens how associations depend on past experiences instead of existing objectively:

\begin{abstract}
Association [...] never comes into play as an autonomous force; it is never the word suggested which "induces" the reply in the manner of an efficient cause; it acts only by making probable or attractive a reproduction intention; it operates only in virtue of the meaning it has acquired in the context of the former experience and in suggesting recourse to that experience; it is efficacious to the extent to which the subject recognizes if, and grasps it in the light or appearance [physiognomy $]^{16}$ of the past (MERLEAU-PONTY, 1962:18).
\end{abstract}

Concomitantly, time and repetitive practice consolidate references. Similar to other members, I cannot tell where a word begins and ends, since I don't know what a word means nor if it is actually a word. Nonetheless, phonemes I repeatedly hear in different contexts, be it in songs or ritual expressions, become gradually "physiognomies of the past": I might not know their meanings, their written form, nor even if I am hearing the same phonemes as before, but my experience of that grouping of sounds forms a physiognomy, which I begin to recognize and relate to when hearing it again.

This was illustrated by Amankwa de Xangô ${ }^{17}$ while drawing a comparison between learning songs in Portuguese and Yoruba:

I can better situate words in Portuguese than in Yoruba for knowing what the song is about. In Yoruba there's no way. The best that can happen is "Oh, that was a word I have already learned it in some other chant and it has probably something to do with Ogum or Oxum". But for knowing what it could actually mean, there's no way (Interview on 12.03.2014, Berlin).

16 In the original, "physionomie du passé" (1945: 45).

17 German male $(30+)$, son of a Nigerian father. 
Amankwa demonstrates that, although we remain linguistically and semantically ignorant about Yoruba, practice sediments its sounds - its sonorous physiognomies in the sense of Merleau-Ponty (1962)- in our bodies. For instance, I don't know what "yakota" means, but I heard it in different songs for Iemanjá and also recall it from a Santería song I was introduced to through an article (MOORE \&SAYRE, 2006) ${ }^{18}$.

When I learned the following song for Iemanjá, I didn't consciously associate it with the Santería song; I only remembered it while reflecting upon the reasons this word became familiar to me. Since then, when I hear Candomblé songs containing "yakota", the word immediately becomes an "anchor" for memorizing the whole lyrics within an infinite ocean of new information to which one lacks appropriate references, as in the following song for Iemanja ${ }^{19}$ :

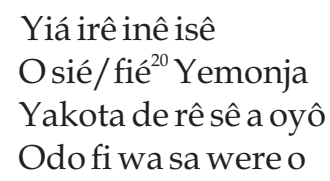

The words Yakota and Yemonja work as anchors for memorizing further phonemes of the chant. After checking the song's lyrics in my archive two years after having learned them ${ }^{21}$, once again I confronted the fragility of memory, for the lyrics above don't exactly correspond to my first handwriting from January 2014. At that time, we wrote down the lyrics the way we heard it from Ogã Paulo, who three months later distributed copies transcribed by me. A comparison of the three transliterations follow:

\begin{tabular}{|l|l|l|}
\hline Nina January 2014 & Ogã Paulo March 2014 & Nina November 2015 \\
\hline $\begin{array}{l}\text { Yaba odê irê ixê } \\
\text { O fié Iemanjá }\end{array}$ & Yabá ode irê ixê & Yiá irê inê isê \\
Yakota de rê sê a oyô & O fi é Yemónjá & O sié Yemonja \\
Odo fi ya xó u e ré ô & Yakotadê-ressê a oyô & Yakota de rê sê a oyô \\
Odofi, yaxô wéré o & Odo fi wa sa were o o \\
\hline
\end{tabular}

On the one hand, the table illustrates time's effect on my memory: the third transliteration lost much information on the phonemes after such a long time. However, my memory "anchors" remained: "ya", "yakotá", Iemanjá, "odo", and "oyo", while "yaba" and "ode" became new anchors after learning the meaning of iabá, the female orixá, as well as that odé is another name for Oxóssi. Surely Oxóssi has nothing to do with this song and the " $\mathrm{e}$ " of his other name is closed and not open, in Portuguese odê instead of odé, but, once the association was made, it became a mnemonic anchor.

On the other hand, the comparison between my first and last versions of these lyrics reveals some "corrections" unconsciously made based on my experience with Yoruba. Besides trying to be "orthographically faithful" by writing Yemonja instead of Iemanjá, today I interpret and write down the sounds in a more approximate way of Yoruba instead of Portuguese: "were o" instead of " $u$ e ré ô". This demonstrates how even by ignoring the semantics of words and lyrics, we develop a "practical sense" (Bourdieu, 1980) for the sounds we are confronted with.

18 In this case, yakotá is the name of a Santería rhythm, however, on Iemanjá's song I still have no information on its meaning.

19 "Yá" and "Odô" also became anchors, for the greeting for Iemanjá is "Odô yá" and very soon I learned that Yá is mother - whereas "odô's" exact meaning I still ignore.

20 Many times I sang this song switching between sié and fié for not being sure about the correct phoneme.

21 The present text was first drafted in 2016. 
To read a word facilitates and shortcuts memorization, while doesn't necessarily condition it. A word, being primarily a sound, "only exists when it is going out of existence", being "evanescent" (Ong, 2002: 31), for even if read in silence, its sound is triggered in the mind of the reader. Writing, "a commitment of the word to space" (p. 7), is, instead, visual and permanent as long as inscribed in some device. At once, reading facilitates learning processes, but also determines and alters the perception and reproduction of a sound. This might happen in distortive ways. At a presentation I gave at Dia dos Pretos Velhos in Forum Brasil on $13^{\text {th }}$ May 2015, I sang a cantiga for Oxalá that became very meaningful to me during my fieldwork in Bahia. In order to practice it and be sure about its lyrics, I searched for it on YouTube. The lyrics were written and translated as follows:

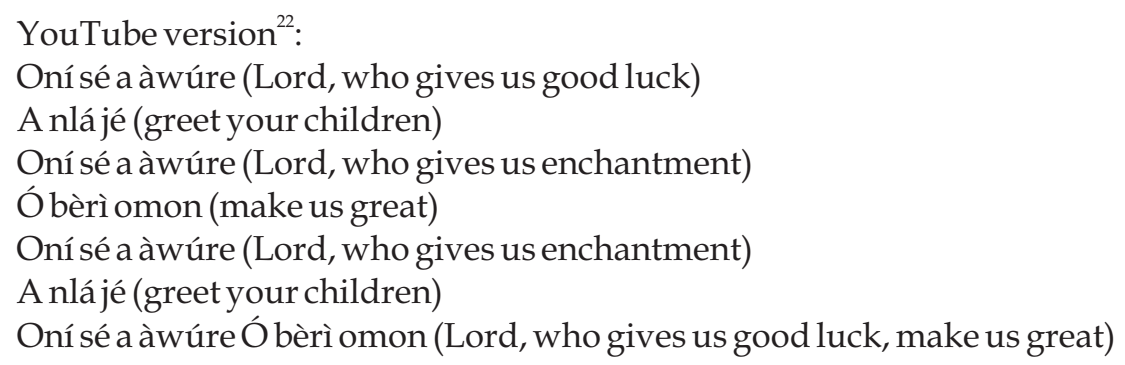

The other version found on different websites was written with Yoruba's special characters:

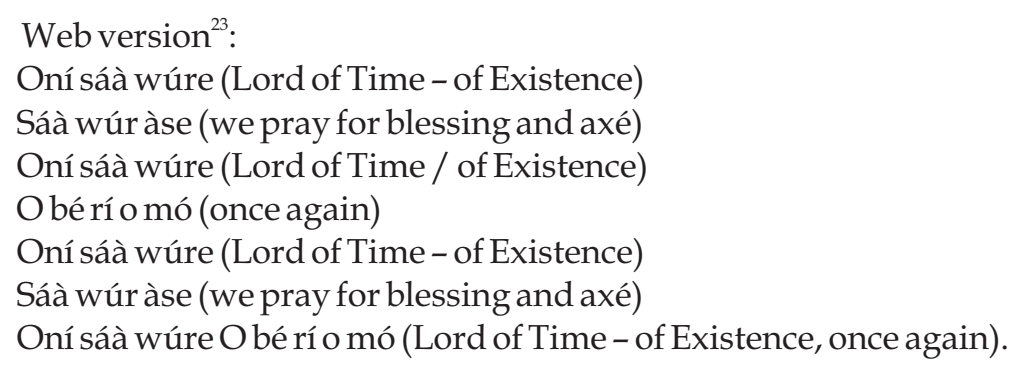

In Yoruba, the letter "S" with point underlined has often a "sh" sound: Xangô is written "shango" in English and Sàngó in Yoruba. However, none of the lyrics found on the internet had special characters and the singers don't seem to pronounce "sá" as "shá". When I sang the YouTube version at Forum Brasil that day, Murah started to sing along and to correct me by emphasizing the inaccurate words with his voice, his glance and hand gestures. From this and other times we chanted this cantiga, the version I have in mind today is the following:

\author{
My current version (February 2020): \\ Onishá urê \\ Saun laxé \\ Onishá urê \\ Obéri oman \\ Babá shá urê \\ Saun laxé Babá \\ Onishá urê obéri oman.
}

22 https://www.youtube.com/watch?v=6pPFW10qtto (last seen on 08.02.2020).

23Among others, http://extra.globo.com/noticias/religiao-e-fe/pai-paulo-de-oxala/oni-saa-wure-senhor-dotempo-louvor-do-candomble-14419374.html (last seen on 08.02.2020). 
Certainly, I interpreted the YouTube lyric mistakenly due to my scant Yoruba knowledge. Some weeks later, however, I noticed Ogã Paulo exchanging a "sh" for an " $s$ " sound as well, in a cantiga de ebó we sing almost every week. Different from me, he did so not in the lack of knowledge, but precisely because of his new Yoruba knowledge. At that time, Ogã Paulo was learning Yoruba with a Nigerian teacher, so I presumed that it had influenced his sudden different way of pronouncing the word. He told me excited about his classes while criticizing the Yoruba spoken in Brazil and I drew his attention to the fact that Yoruba, just as Portuguese, doesn't have one sole, original, authentic or correct way of speaking, for oral traditions are not fixed - literate either. Besides, Yoruba is a pluricentric language, that is, it encompasses several dialects with no standard form.

I asked Ogã Paulo the reason for his sudden change. He was surprised that I noticed and remembered it after some months, since no one else did; that is, no one responded his singing in the same modified way. That is why he never sang it again with an "s" sound: at that moment he understood that the "grammatical competence", as he called it, should not be above the "liturgical competence" ${ }^{24}$. Accordingly, if the Babalorixá uses to sing "sh", Ogã Paulo should respect the liturgy instead of prioritizing a "grammatical correctness" and singing differently.

Yet, Ogã Paulo demonstrated his belief on a grammatical homogeneity and correctness prior to the flexibility, multiplicity and situatedness of orality. I expressed my critique by saying that we might never know if Murah is linguistically wrong, i.e. whether such a word with "sh" ever existed in Yoruba, or whether he sings in a an ancient (or even regional) manner ${ }^{25}$ passed orally to him through generations. Ogã Paulo's attitude towards grammatical correctness reveals a tendency of literate people described by Walther Ong:

Where grapholects exist, 'correct' grammar and usage are popularly interpreted as the grammar and usage of the grapholect itself to the exclusion of the grammar and usage of other dialects. The [...] fact that the grapholect is written or, a fortiori, printed encourages attributing to it a special normative power for keeping language in order. But when other dialects of a given language besides the grapholect vary from the grammar of the grapholect, they are not ungrammatical: they are simply using a different grammar, for language is structure, and it is impossible to use language without a grammar (ONG, 2002: 105).

Respecting Paulos' broader knowledge of Yoruba, I didn't mention the language's pluricentrism and that perhaps he is learning a dialect different from Murah's. We both have a literate way of thinking and are native speakers of a language that, differently from Yoruba, bases on a grapholect - an official standard form. We tend to take the grapholect as the sole truth, while perceiving other forms of speaking, writing or singing as incorrect.

However, there's no normative, official written Candomblé song to learn from; the repertoire chosen, the words and their spelling depend on who is calling a chant and on which moment. For singing Candomblé chants there's no right or wrong, as Murah explained:

Each house is a house, each Candomblé is a world. [...] It is passed on by word of mouth, it has no bible. You may write it down, but I will learn what my pai de santo teaches me. Thus, of course there are cantigas in which there are things that you sing like this, and if you go to another house, there's the same cantiga with other words.

24 Informal talk on 14.11.2015, Berlin.

25 The subject of learning different manners or versions of singing cantigas in Candomblé was explored in a former article (GRAEFF, 2014b). 
And it means the same. It doesn't mean that it changes; it's about using other words. It's like in Portuguese: You might say "I am very lonely" and other person might say "I am very lonesome". They are different words that mean the same thing. [...] So it's not about being wrong, being different; it's the same thing, but with different words. The tradition maintains itself therein (Interview on 03.03.2014, trans. by author).

For Murah, different ways of speaking, singing or dancing are not wrong; they are not even different, they are "the same thing". They express one same essence through different forms (GRAEFF, 2018).

Although writing down sounds facilitate the learning of songs, to read Yoruba words without ever having heard them doesn't guarantee memorization. Simone d'Omolu attributed her difficulties in learning the cantigas in Yoruba the special tonal characteristic of the language:

Nina: Is Yoruba harder to learn as Portuguese?

Simone: yes, fundamentally. Especially because it depends on accentuation.

$\mathrm{N}$ : True, but I never think about that while singing!

S: Me neither, for Christ sake! But the words alone are pretty strange, also for a German ear, actually.

$\mathrm{N}$ : Yes, and one cannot google them, as to know what they mean.

S: No, one cannot find anything. There's no information. Every [Candomblé] house has a particular doctrine. You might find one song maybe, but it will be surely at least slightly different (Interview on 27.02.2015, trans. by author).

Simone also attributes the challenge of learning Yoruba songs to her cultural background, which she labels as "German". In this sense, Amankwa de Xangô shares this background with her. However, he surprised me while confessing that for him, in opposition to Simone and to all other members regardless of their nationality, Portuguese songs for the caboclos (indigenous spirits) are the hardest to learn:

Amankwa: To be honest, to me it's much easier to learn Yoruba songs than the Portuguese chants.

Nina: Really?

A: For instance, to sing to caboclos was much more difficult to me. Yoruba it's easier.

$\mathrm{N}$ : And how come? Simply like that?

A: I cannot exactly explain to you why. But I think I can better separate the Yoruba syllables from each other than in Portuguese, because it's sometimes more slurred, and I cannot tell where a word begins and where it ends (Interview with Amankwa de Xangô on 12.03.2014, trans. by author).

Ironically, Amankwa's perception of Portuguese equals mine towards Yoruba: he cannot tell where words begin and end. When we know words' meanings, however, we perceive their sounds as signs, as words with beginnings and endings, being able to recognize the sentences they build together and the contexts they refer to, memorizing thereby what otherwise seems like abstract sounds. This is the case of cantigas de caboclo (caboclo chants): Even members who don't master Portuguese such as Amankwa de Xangô can simply ask Brazilians any time for the words and meanings of a song - or even try to google it home - while Yoruba remains mostly inaccessible. Simone d'Omolu and Iris d'Ossaim, who could already understand much Portuguese and knew several cantigas, asked me often the meaning of some words during Seu Ventania's singing. 
Abstract sounds as well as scant meanings of words are the few references most members in Berlin have for learning cantigas, for which reason specific contexts must be created for it, such as the weekly rituals. Different tactics of transmission are experimented (GRAEFF, 2014b); the cantigas class by Ogã Paulo were only one of several attempts of teaching cantigas to new and old members. All of them avoid, but do not completely exclude, the use of technology, be it writing, audio recording or the use of external sources such as the internet. In Bahia, in turn, people are said to be "born within Candomblé": since early childhood, they grow up in neighbourhoods and regions pervaded by references of the cultural practice, assimilating that surrounding world as they grow up. Not only lyrics, but rhythms, ritual contexts and dances are tacitly learned as part of every day life in what can be called a "universe of orixás".

\title{
Between a created context in Berlin and the Bahian universe of orixás
}

\author{
So you're already seeing how one learns Candomblé! $!^{26}$. \\ Pai Pote
}

After one and a half year practicing Candomblé once a week in Berlin, I travelled to Santo Amaro, where I would live in the house of Pai Pote ${ }^{27}$, currently one of the town's most requested pais de santo. When on my first days there I briefly explained to him that my research was about how one learns songs, dances and gestures in Candomblé, he reacted with the quotation above. We were sitting in the backyard of his terreiro, where nothing was happening - or, rather, where I still couldn't see anything happening. It took me more than one month to "see" what he meant as well as to see things "happening".

At my arrival, I presumed that in Santo Amaro I would go through the same experience of frequenting a temple once a week as in Berlin. Pai Pote soon informed me that his community gathers together once a year, at most. I was shocked. After his explanation, I presumed that in Berlin Murah had institutionalized Candomblé practice within Wednesdays in the lack of the everyday context. Then I learned that the famous Ilê Axé Opô Afonjá, also meets every Wednesday; thus, I re-considered those weekly meetings could be due to a kétu tradition or to an urban context. Premises kept falling apart while my ethnography in Bahia would embody the paradoxes of both transmitting and researching Candomblé in contrastive contexts.

Whatever reason one might attribute to differences between these temples and practices, only time would reveal that they are not as relevant, since "each house is a house, each Candomblé is a world" ${ }^{28}$. However, the "Candomblé's world" in Berlin mostly limits itself to one house, one pai de santo, one community, and, hence,

\footnotetext{
Candomblé in Berlin is not only out of its context, it is "out of context". Any outsider needs a long explanation of what it is. Here in Santo Amaro the references/associations are taken for granted and may be deep in the sense of uniting both practitioners and sympathizers. In Berlin this can only happen to someone who by chance has already been to Cuba, Brazil, Africa... (Field note from 02.10.2014, Santo Amaro).
}

26 Field note on 09.10.2014, Santo Amaro, transl. by author.

27 Pai Pote (50+), José Raimundo Lima Chaves, is pai de santo of Ilê Oju Axé Onirê, in Santo Amaro.

28 Babalorixá Muralesimbé, interview on 03.03.2014, Berlin, trans. by author. 
Whereas in Bahia conversations about Candomblé and orixás are not only common but taken for granted, in Germany they rarely take place outside the community and the weekly rituals. Once they do, one must explain everything from the beginning, for instance that the orixás are African deities. The references of Candomblé are absent in Berlin, which also means that, among its members, associations take place mainly inside the ritual context.

Being used to practice Candomble solely inside the ritual context, at the beginning of my field research I was separating "ritual" from "everyday context". At a Candomblé festival in Feira de Santana to which I went with filhos de santo of Pai Gilson ${ }^{29}$, I started to realize important distinctions between his and our egbé (community in Yoruba) in Berlin:

\begin{abstract}
In Bahia one "chooses" a community or is already born within it; one chooses a family or already belongs to one, and this family is part of the everyday, going to other festivals all together as we did yesterday. In Berlin, those who want to practice Candomblé only have Ilê Obá Sileké as option. We stayed all together in the backyard during the festival yesterday, even though some filhos knew many people from other terreiros. There, they talked about other groups and tightened their bond. Sometimes they heard a song coming from the barracão [main room] and commented on its meaning, on why the caboclo sings it at that moment. At the end, they chatted about internal issues of their egbé. They were upset because Pai Gilson didn't come (Field note on 12.10.2014, Santo Amaro).
\end{abstract}

At that big caboclo festival, a wide web of povo de santo (Candomble members) came together: diverse famílias de santo ("families in saint") and relatives ${ }^{30}$ met in another town. Pai Pote attributed the fact that so many practitioners from different houses and regions know each other to "It's the orixás, it's a web, right? This is a web of love, a web of prosperity, a web of goodness. So you get to know people" (Interview on 28.01.2015, trans. by author).

They met not only for greeting each other and spending time together, but also in the sense of sharing knowledge. They shared knowledge regarding the tradition, about songs and their meanings; knowledge regarding other communities, while strengthening their identity and bonds; as well as knowledge about their own family, by organizing forthcoming festivals, sharing discontentment about the absence of their pai de santo, etc. "It seems typical of apprenticeship that apprentices learn mostly in relation with other apprentices" (LAVE \& WENGER, 1991: 93).

In Berlin, conversations on the dynamics of Ilê Obá Sileké - or simply ilê - take place as well. Nevertheless, one enormous distinction lies precisely in the absence of such a wide web. Ilê is also a web, with members all over Germany and with Murah's "family in saint" in Brazil. We often receive his brothers and sisters in saint visiting Berlin, but our only common point is him. Only indirectly, and very distantly, are we connected to his web of povo de santo, of which his own ties got loose after decades living in Europe. Consequently, we rarely have a "mirror", as I had in Bahia, for reflecting upon and making sense of Candomblé, of our practice as well as of our community. As mentioned in the field note, a family in saint strengthens its identity and, thus, emotional ties precisely through alterity. By experiencing the rituals of other families of saint, their ways of clothing and singing, they make sense of their differences, characteristics and identity.

29 Gilson Cruz (50+), pai de santo of Ilê Axé Omorodé Loni Omorodé Oluaiê, in Santo Amaro.

30 Candomblé communities are seen and referred to as families. 
The same is valid for Murah on another level. He did have "mirrors" while living in Brazil, and he still mirrors the tradition of his own mãe de santo in ilê. However, the mirrors of other rituals, communities and pais de santo are absent in Berlin's every day. To be born and raised interwoven in this web means to assimilate those references mimetically, that is, by means not only of imitation, but of appropriation of the world (GEBAUER \& WULF, 1991) that constitutes the web. Such context differences lead to the difficulties of Berliner practitioners to learn cantigas:

\begin{abstract}
Candomblé is initiatory practice... I learned much because I dwelled twenty years in a Candomblé house. So I sang every week. I learned quickly because I dwelled there, the practice took place every day. Here is much more difficult, first because we are in Germany: the language is foreign, it's different. Brazilians learning in Germany face another challenge of speaking two further languages: German and Yoruba. Germans as well must learn Portuguese and Yoruba; it is even harder. At the same time, people are not constant, they only come once a week. Once a week is much harder to learn, you forget it very quickly. They don't stay inside the practice. And sometimes they come one week and the other they don't. So they forget. Thus, it becomes much more difficult, one learns everything by practice(Interview with Murah on 03.03.2014, Berlin, transl. by author).
\end{abstract}

The religious practice remains restricted to the rituals taking place inside the terreiro. Consequently, the frequency of rituals and, hence, the continuity of practice are low, hampering transmission. In the past - a past with no technology -, people could and would "dwell" for long periods in a terreiro, learning 24-hours a day and, hence, "habituating" (BOURDUEI, 1972) the tradition. Nowadays, the discursive rule is to stay secluded at least twenty-one days, while in practice seclusion might last even shorter - a reason of critique by elders. Diverse social changes led to new ways of transmitting Candomblé, one of which very recent: some elders like Murah hold the opinion that Candomblé apprentices must make much effort for acquiring knowledge, instead of shortening apprenticeship through the use of technologies such as the internet. Pai Pote, on the contrary, holds that the "internet is good for everything"

\title{
"Internet is good for everything!" - technology as tool or taboo
}

In Santo Amaro, the orixás recently became omnipresent beyond the real and physical world, also inhabiting the virtual world of internet. During two trips for my research on samba de roda in 2010, the digital world was only beginning to enter the reality of teenagers in Santo Amaro, who would spend money and hours at LAN-houses playing video game or using Orkut - the social network widespread in Brazil before Facebook became the main trend -, since only a few could afford having computers at home. In 2014, the consequences of Lula's social policies ${ }^{32}$ leading to the eradication of extreme poverty and increase of the consuming power of lower classes became evident in the region: nowadays everyone has LED-TVs, home computers, smartphones and even tablets. The internet and, parallel to it, overall publicly accessible information about Candomblé turned into everyday life.

During my fieldwork, several moments of film elicitation (Krebs, 1975) took place as spontaneously as the everyday life in Santo Amaro. 
Before showing the videos to people taking part in them, I imagined their excitement about watching themselves and the beautiful ceremonies on the screen. Instead, their overall reaction was rather indifferent, of staring at it as at any other entertainment. Whereas I presumed that the streaming would provoke "a break in the routines" by triggering enthusiasm, it was taken for granted. In 2010, people would see my photo camera and ask me to take a picture of them, getting excited about seeing themselves on the camera's screen. In 2014, in turn, everyone was taking "selfies" and recording videos with their smartphones everywhere, including during Candomblé rituals and for making portraits with the orixás in trance, as if orixás were TV stars.

I remember when Áries d'Ossaim ${ }^{33}$ entered our living room asking me to upload some cantiga and to configure it as ringtone in his first smartphone; he got delighted and asked me another one of his orixá, Ossaim. I remember to be in a cloth shop in the city centre and to hear someone's ringtone playing a song for Oxalá. I remember so many times in which I was working on my computer and Thiago ${ }^{34}$ would ask me to open YouTube so we could listen to cantigas or watch videos of rituals, and in which Pai Pote asked me to take pictures and upload them for him on Facebook or made selfies of us.

Compared to my experience in 2010, the routinized presence of technology and especially of the internet in Santo Amaro was surprising. But the most astonishing was to realize the natural handling of Candomblé practitioners with it. In Berlin elders constantly reiterated the importance of "initiatory practice" for learning. As a matter of fact, in ile the use of technology for learning is taken almost as a taboo:

\begin{abstract}
Amankwa recorded [the audio with his smartphone] while Babá [Murah] or João Dofono de Xangô $\hat{o}^{35}$ sang and Babá [Murah] complained: One shouldn't record; one must sing; one learns by singing. I took pictures of Maria's ${ }^{36}$ lyrics and he reprehended me, saying that he didn't want this to get out of the house, that he doesn't like that people take pictures and record; one has to learn by singing, that's how he learned. [Murah:] "The cantiga has to be in the head, not on the paper. The paper disturbs (at the moment of reza), because it deviates the concentration, which should be on the orixá". Then I said "so I better handwrite?" - since everyone had done it - and he said no, that this shouldn't happen either, that he didn't learn with paper (Field note from 09.10.2013, Berlin).
\end{abstract}

First, I assumed that Murah was prohibiting us to use technical devices for taking pictures and recording the songs, which shorten the learning path. But he didn't want me to write the lyrics down either. He was rather instructing us to learn according to "incorporating practices" instead of to "inscribed practices" of acquiring and transmitting knowledge (CONNERTON, 1989), while discarding all devices of inscription, like recorders, cameras and even written words. The latter, for remaining accessible even after the disappearance of their source - a performer, writer, priest - imply a "will to be remembered" (CONNERTON, 189: 102), in opposition to the ephemeral and "traceless" incorporating practices. Babá wants his filhos de santo to practice cantigas towards their incorporation, that is, towards their register "in the head" and not on paper or any other storage device.

That first assumption lied in one of my first fieldwork experiences in Berlin, in which I transcribed song lyrics to a whiteboard. João Dofono de Xangô told me that writing down helped to learn, for demanding an extra effort that reading doesn't, for which reason we also transcribed some lyrics several times.

33 Áries d'Ossaim was an iaô (new initiate) living with Pai Pote for some obscure reason - his own pai de santo was from another city - while I was living there.

34 Grandson of Nicinha do Samba (60+), with whom I was living in Santo Amaro. At the time, Thiago was 13 years old and after some months was requested to be initiated as ogã of Pai Pote's temple.

35Brazilian actor and pedagogue (40+) and first initiate of Ilê Obá Sileké.

36 Maria de Iemanjá (60+), Brazilian woman.

EntreRios - Revista do PPGANT -UFPI -Teresina • Vol. 2, n. 2 (2019) 
When Murah told me to stop photographing others' lyrics, I interpreted it as an indication towards handwriting for making such an effort, but he wanted me in fact to make a much greater effort towards getting them "in the head". Precisely on that day, we had repeated four songs uninterruptedly for so long that I began to feel dizzy: my brain got indeed racked.

When arriving in Santo Amaro, I supposed that Murah's discourse would be implicit in the practice so that believers would learn "without paper", that is, solely by incorporation, similar to his apprenticeship. In Bahia, handwriting lyrics or employing the internet wouldn't even come into question for being Candomblé's context of oral transmission. However, another facet of such "oral transmission" came up when Mãe Lina "examined" my Candomblé knowledge without much success for my lack of knowledge about the meaning of some Yoruba words:

\begin{abstract}
She started telling me words in Yoruba and asking if I knew what they meant; I didn't know any. [M. Lina:] "shanan? It's matchstick... You didn't learn anything!" [Nina:] "But I have only learned for one year, there's so much to learn" and she said "I learned everything!". I told her that my pai de santo even speaks some words in Yoruba, but only once, so we forget it. She said that one must "copy" [write down]; that she learned because she copied everything and that's how they learn [in her house], by "copying" together every Friday. The iaôs [new initiates] sleep over there on Thursday [...] and "learn everything", they "write down everything", the words, the cantigas (Field note from 05.11.2014, Santo Amaro).
\end{abstract}

Mãe Lina's reaction opposes Murah's positioning against writing down the lyrics. Whereas he affirms that he "didn't learn with paper", she states to have "learned everything" precisely by "copying", that is, by handwriting lyrics, Yoruba words and recipes "on paper". She uses the same transmission method with her initiates, who spend every Friday at her house "copying everything".

Mãe Lina's remarks account for another realm of Candomblé's transmission: the use of written sources. Castillo (2008) demonstrated how written documents are very constitutive of Candomblé: every initiated keeps a caderno de fundamento, a notebook for storing ritual knowledge. However, the information stored shall neither become public nor be shared with other individuals for protecting the "secret" - or rather a "body of knowledge of restrained circulation" (op. cit., p. 25). For Castillo, this is a strategy of power maintenance over the knowledge access that corresponds to the liturgical hierarchy (id., p. 26). In my practical perspective, however, to "protect" Candomblé's "secret" is rather a way of maintaining the religion's values and modes of transmission, similarly to Prandi's explanation:

\begin{abstract}
Elders are bearers of people's living culture and the conviviality with them is the only way of learning what they know. [...] The elder holds the tradition's secret. His word is sacred, for it's the only source of truth [of knowledge]. This way of conceiving apprenticeship and knowledge goes into crisis when literate members begin to draw on written formulas that gradually appear in books and other types of publication (PRANDI, 2001: 53, trans. by author).
\end{abstract}

Because elders hold the secret, their words are sacred. The interplay between secret and sacred was invoked in one of my first individual rituals. After it finished, Murah advised me not to tell others about it, not for the sake of secrecy, but for keeping the ritual's axé for myself, otherwise it would scatter. To "keep secret" means to "keep sacred": it is a way of concentrating energies only among those who are sharing it. The same applies to sharing knowledge: "Candomblé is preserved through the secret. Without secret, Candomblé doesn't exist" ${ }^{37}$.

37 Pai Pote, interview on 28.01.2015, Santo Amaro, trans. by author. 
Prandi does mention the "dependence" of communal life on the wisdom of elders, but not in the sense of being "controlled" by them, as Castillo suggests. Instead, he recognizes that "one knows more because one is old; because one has lived through the necessary time of apprenticeship" (PRANDI, 2001: 52, trans. by author). From this, a second reason for the rejection of written sources for apprehending the religion emerges: the primacy of experience in learning. Prandi argues that "until nowadays, in Candomblés from Brazil one seeks to instruct that experience is the key for learning" in Candomblé" (id.), the same way that Murah instructs us in Berlin.

Once this experiential conception of apprenticeship is threatened by "written formulas" and by inscribed knowledge available anytime and anywhere, conflicts arise. This is as true for the cultural context in which Prandi does his research since decades, the urban context of São Paulo, as well as for Berlin, where Murah is alone in transmitting the tradition. In contrast, in Bahia's countryside, the perception over inscribed knowledge is very different, as demonstrated by Pai Pote's immediate reaction to my question:

\footnotetext{
Nina: People are pretty much using internet for learning, isn't it?

Pote: This is good, internet is good for everything! The internet is bad when used in a bad manner, in bad faith. But the internet has also good things that are important for us. So for me, in my way of thinking, in my ideology, the internet is very good. It depends on each person using it, putting things [online] in the right way - but everyone in the right way doesn't exist. So you must also research and see which one is the right way.

$\mathrm{N}$ : But doesn't it happen sometimes that someone reads something different on the internet and argues about it?

P: Everything is different. Everything is different. Each one learns a way in his [Candomblé] house, got it? (Interview on 28.01.2015, Santo Amaro, trans. by author).
}

Pai Pote immediately recognized the use of internet in a fully positive way, not only for learning, but "for everything". At the same time, he acknowledged the existence of unreliable information sources uploaded "in bad faith", while not regarding it as a problem. Instead, he considers it an inherent aspect not only of internet content on the religion but of Candomblé's very multiplicity: there's no sole truth, "a right way", valid for everyone. Furthermore, Pote suggests one can easily overcome unreliable sources by "researching" and looking for "the right way".

What Pai Pote considers positive, for Murah poses a problem. Once, Murah started to undertake what we ironically call a "sabatina", a sequence of questions recapitulating something taught, this time on basic information about the orixás. He began by asking members about orixás' colours. For my astonishment, almost no one guessed them correctly, not even Amankwa on his own orixá Xangô, who is red and white:

Aman also answered that the colours of his Xangô (with a specific quality) were white and
silver, that he saw it on a picture [on the internet]. Babá began to say that many things on
the internet are "richtig, aber viele sind total blöd und das macht durcheinander (correct,
but others are totally stupid and only confusing). One must learn within the house and not
keep "fußen", weisst du, was das ist? (Do you know what this means?) To keep
rummaging ("fuçando", verbatim to smell with the snout)." (Field note from 09.10.2013,
Berlin).

At the time of my master studies in 2010, I couldn't find videos about orixás on YouTube, only one that showed Iansã's dance in a profane event. 
Nowadays, there are thousands of entries for diverse types of rituals, theatre, dance classes, movies, telenovelas relating to Candomblé; the internet makes endless information available. Whereas it enables worldwide accessibility to rich information on Candomblé from reliable sources, it also brings up blöd information, meaning both nonsense information as well as secret knowledge that should not become public - an example of internet use in "bad faith".

The reasons for the first case of mistaken or nonsense information are numerous. First, there is no control on who shall upload it, if pais de santo, iaôs, or even individuals with no religious experience. Secondly, different nations and religions have different interpretations over the orixás. For instance, Oxum, known even in Cuba for being yellow and gold, in some Umbanda segments is light blue. Third, each "Candomblé (house) is a universe", construing each religious meaning in a particular form, according to the experiences of its spiritual leader for which reason "everyone in the right way" doesn't exist.

Therefore, someone with scant Candomblé experience won't be able to distinguish between "stupid" and "bad faith", i.e. from good and trustful information. "Trustful" also in the sense of corresponding to the interpretation of one's own house: it might be that for some quality of Xangô or some nation his colours are white and silver. However, at Ilê Obá Sileké (and most kétu houses), Xangô's general colours are red and white. Since Amankwa's Candomblé experiences were limited to Berlin, he guessed it mistakenly, believing on a picture found on the web. For this reason, Amankwa should stop "rummaging" and getting "confused" (durcheinander) by using the internet, and learn instead "within the house". Only then he would be able to research and find the "right way", as Pai Pote suggested, distinguishing the "wrong" from the "right forms" in accordance to his own Candomblé house and practice.

With the intention of learning more about his orixá and Candomblé, Amankwa "rummaged" on the web. Once he took silver and white colours for right instead of the colours we use in ilê, he was stating the primacy of the former over the latter. At least in this example, he took the internet as a more valuable source of knowledge than his own experience. Sound recordings, videos, written material also work as mimetic models (GEBAUER \& WULF, 2003: 111) to imitate, and, thus, as authorities in the transmission of knowledge (GRAEFF, 2013, 2014a), so that their power may even overcome one of living authorities, such as the elders. Despite Pote's optimism about the use of the internet, I had learned a similar conflict happening in Santo Amaro. Anthropologist Hannes Leuschner ${ }^{38}$ told me a case in which an iaô confronted his pai de santo with internet information, taking it for the most reliable source. Whereas Hannes, as Castillo, considers it a risk for Candomblé's hierarchical dynamics, Pai Pote didn't take it as problematic as theoreticians use to. As a matter of fact, he even laughed about it:

Nina: I think it was João [Hannes] who told me that at some [Candomblé] house someone told his pai de santo that something was written in a different way on the internet and that the internet was correct [and not the pai de santo]:

Pai Pote: (Laughs) that's a conflict, but it's good, internet is always good.

$\mathrm{N}$ : Yeah, right? Because one has the possibility of learning.

PP: Exactly.

$\mathrm{N}$ : Thiago is always listening to cantigas there, learning with the internet...

PP: Doyou see?

$\mathrm{N}$ : Because... one cannot be every day at the terreiro learning...

PP: Exactly, so we stay on the internet singing (Interview on 28.01.2015, Santo Amaro, trans. by author).

38 Author of the book on Candomblé de Caboclo in Santo Amaro (2011), living at the time in Santo Amaro for his Ph.D. research. 
Although calling the narrated case a "conflict", Pai Pote doesn't attach importance to it. Practitioners seem not to attribute as much relevance to the paradoxes of internet use as researchers or other literate people: most websites copy-paste information from each other. By searching a topic as, for instance, "Oxum's features' on Google, one finds over a hundred thousand results from different nações, religions and regions with the very same text for it. Similarly, several websites or YouTube channels use the same sound recording coined as "Candomblé's hymn" or the same orixás' drawings made by Bahian artist Carybé as illustration. It is not so relevant what or how something is written and represented; what matters is the orixá's presence everywhere, including in the web.

Newcomers like Amankwa tend to give registers primacy over practice, believing in the existence of a single truth. In my last days of fieldwork in Bahia I showed the book Cantando para os orixás (OLIVEIRA, 2007) to different persons in Santo Amaro for observing their reaction. The book written by Ogã Ailton B. Oliveira brings over three hundred cantigas kétu with Yoruba lyrics and their Portuguese translation. From the Yoruba phonetic translations, I could only recognize a few songs, for most lyrics diverge largely from the ones I learned:

I showed Thiago the book "Cantando para os orixás" and he'd sing differently from it and we'd compare it with a YouTube video with lyrics and translation. The translations had nothing to do with each other; one talked about sword, the other about palm leaf. He would say that the lyrics were wrong. Then Pote came up and I showed them to him. He said that he knows the author, who did a serious work and died last year. Pote started reading it through: he would read the lyrics and immediately start to sing, then check the translation and agree with it. In one of them, it was written "igui", then he said: "igui is tree, want to check?" Then we would find no tree in the translation, but he would simply continue... He talked about the different versions, sang them, agreed when I said that the lyrics were different because the meaning changes. Then he stated that everything was correct; that the book and the author were very good. So I told Thiago "do you see? It wasn't wrong! He knows everything!" and Thiago replied "yeah, he is Baba[lorixá]!" (Field note from 24.01.2015, Santo Amaro).

What for Thiago and me was full of mistakes, for Pai Pote was taken for granted. For him, just as for Murah, there was no matter of "right" and "wrong"; he recognized the quality of Oliveira's work and interacted naturally with it, reading the lyrics, translations, recalling the songs and immediately singing them - even if with different lyrics. He even told me to "check" his Yoruba knowledge by guessing the meaning of "igui" before reading the translation. The fact that his interpretation - "tree" - diverged from the book didn't matter either; Pote kept "practicing" what was written, instead of judging and putting it into question. When mentioning the different ways of singing in our interview, he replied "first, that's due to one's voice. Second, to the tonality. And third... actually even Portuguese is differently spoken, right? It depends on the places [one comes from]." (Interview on 28.01.2015, Santo Amaro, trans. by author). Pai Pote acknowledges the situatedness (LAVE\& WENGER, 1991) of Candomblé's practice and knowledge.

Thiago, Ogã Paulo, who also condemns the reliability of the book, and me tend to take our little knowledge of Candomblé as the truth - as a grapholect truth - since it's our only experience of it, the only "truth" we have learned so far. We strive at confirming our experiences with sources considered as legitimate, like those coming from Salvador's most prominent houses, while rejecting others. In opposition, elders such as Pai Pote and Babá Murah, for having long and diverse experiences with the religion since birth, appreciate the multiplicity and flexibility of "truths". 
This doesn't mean that they don't judge and even mock other Candomblé forms, but they accept and respect them as "true", knowing that "everyone in the right way doesn't exist" (Pai Pote in interview, 28.01.2015, Santo Amaro). There might be a "right way" for Murah and another "right way" for Pote, but none of these is generally valid nor exclude the other. Thus, why does the use of internet, audio, recordings or written lyrics become a kind of taboo in Berlin?

Babalorixá Muralesimbé reprehends the use of technology while not forbidding it: depending on the context, he even supports it. Although at that day Murah stated that one shouldn't write down, one year later he would tell members to "copy everything" on their cadernos de fundamento, which he also possesses since youth. Moreover, Murah even allowed me and Ogã Paulo to record him as to help members to learn the songs. Besides, Ogã Paulo could only learn most cantigas and drum rhythms through the use of the internet, videos and recordings.

Hence, during our ritual days, Murah often reprehends, and even momentarily forbids, the use of technology at the level of discourse, but not of practice. Through his discourse, he transmits us a traditional value that our decontextualized rituals cannot convey: the primacy of (regular) practice. One must come every Wednesday and learn "inside the house" and not outside with "paper", recordings and internet, since "Candomblé is initiatory practice" and "one only learns to sing by singing". In Berlin, Candomblé is "apart" from Germany's everyday context, whereas

in Brazil, Candomble is part of culture, is not something apart from it like here. Why is it apart here? Because it's not part of German culture. We live in Germany (...), people don't have the habit of going to Candomblé, the habit of singing a song like "nessa cidade todo mundo é d'Oxum", which is a popular song, a radio song, but which thematises Oxum, so that people get to know what Oxum is (Babalorixá Muralesimbé, interview on 03.03.2014, Berlin).

Outside Candomblé's cultural context, its transmission must be much more institutionalized. As a consequence of detaching a culture from its original context, the need of discursively explaining - legitimating - its rules and values arises:

\footnotetext{
The problem of legitimation inevitably arises when the objectivations of the [...] institutional order are to be transmitted to a new generation. At that point, [...] the selfevident character of the institutions can no longer be maintained by means of the individual's own recollection and habitualization. [...] In order to restore it, and thus to make intelligible both aspects of it, there must be "explanations" and justifications of the salient elements of the institutional tradition. Legitimation is this process of explaining and justifying (BERGER \& LUCKMANN, 1967: 93).
}

Explanations and justifications are the means by which Babalorixá Muralesimbé can transmit implicit, self-evident values of Candomblé practice outside its universe of practice, translating them into the level of discourse. When he discursively rejects the use of technology, he is highlighting the value of experiencing Candomblé, of being present and practicing it for sharing and acquiring knowledge and axé. He must frequently stress aspects of the religion that are taken for granted in Santo Amaro, where the practice of Candomblé pervades everyday life.

In Bahia, most values and rules are not only implicit and taken for granted, but also the use of the internet. The povo de santo in Bahia is a huge web of pais de santo and filhos de santo supporting each other. Such web has also transcended the physical proximity of Candomblé members, becoming virtual. One night, Pai Pote came into the living room while checking his brand new smartphone: 
Later, Pai Pote came back with his cell phone showing a group chat of pais de santo on WhatsApp. The messages were audio recorded, sending blessings, each one offering a cantiga. Then he would show me and say that he didn't know some songs he had just learned; he showed me how he'd do it, by replaying the recording several time. Then he made me record it! Because he had already told me to pick up my sound recorder for teaching me a prayer for Oxum. He said he would do it very theatrically, which he did, while explaining its meanings. But he only let me record it after his explanation, singing with no interruption. We recorded many cantigas (Field note from 24.01.2015, Santo Amaro).

The web of pais de santo was turned into a WhatsApp group for exchanging information, blessings and cantigas. Pote didn't know one of the songs and started repeating it, showing me his own learning process while declaring that even a pai de santo is always learning. Even a pai de santo never concludes his learning, for Candomblé's knowledge is endless. Pai Pote acquires new knowledge the way children like Thiago do, by participating in his "community of practice" (LAVE \& WEGER, 1991), which is a large "web of love" sew by orixás and the povo de santo. This web is composed of everyday relations, activities, references and models to imitate, of which the internet represents but one aspect.

\section{Conclusions}

To understand the meanings of cantigas de Candomblé, to master its liturgical language Yoruba, and to accurately reproduce Candomblé's singing, cooking or dance techniques are far from being an end in itself (GRAEFF, 2018); they are rather means of communication with the orixás (GRAEFF, 2014b). For "the primordial thing is that you be present, with the energy present there, present with your head, present with your heart." (Babalorixá Muralesimbé, interview on 03.03 .2014 , trans. by author) In this sense, technology may act as a learning support, but not as the main means of transmitting Candomblé. While shortcutting learning, it shortens apprenticeship, for the embodiment of Candomblé's meanings and values takes place through experience and time.

Accordingly, "internet is good for everything" even if it causes some conflicts of reliability and authority inside a huge web of cultural references that continually constitutes the Bahian universe of orixás. Conversely, internet "brings confusion" when overlaying the sparse and intermittent cultural references of a context created outside its universe of practice, such as Berlin. The internet potentializes the possibilities provided by technology - written texts, recordings, videos, and further storage devices - of reproducing a fragmented knowledge at anytime and anywhere. Such fragmented information is nowadays 24 hours accessible, while access to Candomblé's practical knowledge in Berlin is limited to a few hours a week. In institutionalized contexts like Ilê Obá Sileké in Berlin, one learns Candomblé; in Bahia, one breathes the orixás.

Thus, the internet acts as one among an immensity of cultural references of Bahia's "universe of practice" (BOURDIEU, 1980). Within a context created for the transmission of Candomblé in Berlin, however, it works as a virtual universe, with much more references than the German everyday reality can offer. In order to compensate transmission gaps in Berlin, traditional values must be explicitly emphasized, and technology discursively rejected. Practice, discourse and technology interact at multiple levels and within each of the contexts situatively. When the maintenance of Candomblé's traditional values is guaranteed, be it implicitly as in Santo Amaro, or more explicitly and discursively as in Berlin, practice and technology don't cancel, but complement each other. They are all interwoven, be it locally or globally, in Candomblé's "web of love". 


\section{Bibliographic References}

AYOH'OMIDIRE, Félix. Yorubaianidade Mundializada: o reinado da oralitura em textos yorubá-nigerianos e afro-baianos contemporâneos. PhD dissertation, Universidade Federal da Bahia, Salvador, 2005.

BERGER, Peter. L.; LUCKMANN, Thomas. The Social Construction of Reality: a treatise in the sociology ofknowledge. New York: Anchor books, 1967.

BOURDIEU, Pierre. Esquisse d'une Théorie de la Pratique: précédé de trois études d'ethnologie kabyle. Genève: Droz, 1972.

. Le Sens Pratique. Paris: Éditions de Minuit, 1980.

CAPONE, Stefania. Os yorubás do novo mundo: religião, etnicidade e nacionalismo negro nos Estados Unidos. Rio de Janeiro: Pallas, 2011.

CASTILLO, Lisa E. Entre a Oralidade e a Escrita: a etnografia nos candomblés da Bahia. Salvador, Bahia:EDUFBA, 2008.

CONNERTON, Paul. How Societies Remember. Cambridge, New York: Cambridge University Press, 1989.

FREITAS, Ricardo. O. "Candomblé e mídias digitais: sobre a publicização do sagrado e do privado na Internet". Revista Tabuleiro de Letras, 13/2 (dez. 2019). p. 158-172.

. “Candomblé e Mídia: Breve histórico da tecnologização das religiões afrobrasileiras nos e pelos meios de comunicação". Acervo 16/2,(dez. 2011). p. 63-88.

GEBAUER, Gunter.; WULF, Christoph. Mimetische Weltzugänge: Soziales Handeln - Rituale und Spiele-ästhetische Produktionen.Stuttgart: Kohlhammer, 2003.

GOLDMAN, Marcio. "Formas do Saber e Modos do Ser: Observações Sobre Multiplicidade e Ontologia no Candomblé”. Religião e Sociedade, 25(2), 2005: 102-120.

GRAEFF, Nina. “Experiencing Music and Intangible Cultural Heritage: Some Thoughts on Safeguarding Music's Intangible Dimension". El oído pensante, 2(2), 2013: 1-21. http://ppct.caicyt.gov.ar/index.php/oidopensante

. "Ich werde mein Orixá. Mimetische Prozesse in der Weitergabe des Candomblé in Berlin. Paragrana, 23/2, 2014a: 216-228.

. “Transmitiendo y preservando lo ,inmaterial' en una casa de candomblé en Berlín”. Ensayos: Historia y Teoría del Arte ,25/17, 2014b: 23-37.

Oxum's mirror: Embodying Candomblé Transculturally. Ph.D. thesis. Free University of Berlin, November 2016. 
through songs and dances in Berlin". Revista Orfeu 3/2 (2018). p. 44-71.

HALL, Anthony. "From Fome Zero to Bolsa Família: social policies and poverty alleviation under Lula". Journal of Latin American Studies, 38/04, 2006: 689-709.

KREBS, Stephanie. “The Film Elicitation Technique.” In: HOCKINGS, Paul (org) Principles of Visual Anthropology. The Hague: Mouton Publishers, 1975. pp. 283-302.

LAVE, Jean; WENGER, Étienne. Situated Learning: legitimate peripheral participation. Cambridge, New York: Cambridge University Press, 1991.

LEUSCHNER, Hannes. Die Geister der neuen Welt. Religiöse und soziale Integration von brasilianischen Geistwesen im Candomblé von Santo Amaro, Bahia, Brasilien. Berlin: Lit, 2011.

MATORY, J. Lorand. Black Atlantic Religion. Tradition, Transnationalism and Matriarchy in the AfroBrazilian Candomblé. Princeton and Oxford: Princeton University Press, 2005.

. "The Many Who Dance in Me: Afro-Atlantic Ontology and the Problem with 'Transnationalism". In: CSORDAS, Thomas (org) Transnational Transcendence. Berkeley: Univ. of California Press, 2009. pp. 231-262.

The Fetish Revisited: Marx, Freud, and the Gods Black People Make. Durham: Duke Univ. Press, 2018.

MERLEAU-PONTY, Maurice. Phenomenology of Perception. Trans. by Colin Smith. London: Routledge \& Kegan Paul Ltd, 2005 [1945].

MESSIAS, Ivan. S.; DANON Carlos. A. F.. “Internet e Religião: O Candomblé de Youtube”. Revista Psicologia, Diversidade e Saúde, 6/1, fev. 2017: 50-61.

MOORE; Robin.; SAYRE, Elizabeth. “An Afro-Cuban Batá Piece for Obatalá, King of the White Cloth." In: TENZER, Michael (org) Analytical Studies in World Music. Oxford, New York: Oxford University Press, 2006. pp. 120-60.

OLIVEIRA, Altair B. Cantandopara os Orixás. 4. ed. Rio de Janeiro: Pallas, 2007.

ONG, Walter J. Orality and Literacy: the technologizing of the Word. Florence: Taylor and Francis, 2002 [1989].

PEREIRA, Maíra C. A. P.; CAPUTO, Stefania. G.. “Dialogando com narrativas digitais e aprendizagens nos terreiros de candomble'. Revista Tempos e Espaços em Educação 14, 2014: 45-52.

PRANDI, Reginaldo. Os Candomblés de São Paulo: a velha magia na metrópole nova. São Paulo: Hucitec \& Edusp, 1991.

\footnotetext{
África para as religiões afro-brasileiras". Revista Brasileira de Ciências Sociais 16/47, 2001: 43-58.
} 
PREVITALLI, Ivete M. “Tradição oral e novos mecanismos de aprendizado nos terreiros de candomblé". Revista Brasileira De História Das Religiões 7, 2014. p. 275-287.

SANTOS, Boaventura S. "Beyond Abyssal Thinking: from global lines to ecologies of knowledges." Review XXX, 1, 2007:45-89.

SANTOS, Maria Stella de A. Meu Tempo é Agora. $2^{\text {nd }}$ edition. Salvador: Assembléia Legislativa do Estado da Bahia, 2010.

WELSCH, W. “Transkulturalität. Lebensformen nach der Auflösung der Kulturen". Information Philosophie 2, 1992: 5-20. 